The Chinese saying on the cover has been used as a motivation for the International Atomic Energy Agency radiation and tissue banking programme. 


\section{Aduances in \\ Tissue Banking \\ Vol. 7}




\title{
SERIES IN ADVANCES IN TISSUE BANKING
}

Editor-in-Chief: G. O. Phillips

\author{
Published \\ Vol. 1 Advances in Tissue Banking \\ edited by $G$. O. Phillips et al. \\ Vol. 2 Advances in Tissue Banking \\ edited by G. O. Phillips et al. \\ Vol. 3 Advances in Tissue Banking \\ edited by G. O. Phillips et al. \\ Vol. 4 Advances in Tissue Banking \\ edited by G. O. Phillips et al. \\ Vol. 5 The Scientific Basis of Tissue Transplantation \\ edited by $A$. Nather \\ Vol. 6 Advances in Tissue Banking \\ edited by G. O. Phillips \\ Vol. 7 Advances in Tissue Banking \\ edited by G. O. Phillips
}




\title{
Aduances in \\ Tissue Banking \\ Vol. 7
}

\author{
Editor-in-Chief \\ Glyn O Phillips \\ Research Transfer Ltd, Cardiff, Wales, UK
}

This is a special volume associated with the World Congress of Tissue Banking held in Boston, USA, to which all international Tissue Banking Associations contributed. The International Atomic Energy Agency provided from their extensive tissue banking programme. Thanks, in particular, are due to Dr Sam Doppelt and Jorge Morales for their support.

Regional Editors

A Nather (Asia Pacific) National University Hospital Tissue Bank, Singapore

D M Strong (North America)

Puget Sound Blood Center, USA

$\mathbf{R}$ von Versen (Europe)

German Institute for Cell and Tissue Banking, Germany 


\section{Published by}

World Scientific Publishing Co. Pte. Ltd.

5 Toh Tuck Link, Singapore 596224

USA office: Suite 202, 1060 Main Street, River Edge, NJ 07661

UK office: 57 Shelton Street, Covent Garden, London WC2H 9HE

\section{British Library Cataloguing-in-Publication Data}

A catalogue record for this book is available from the British Library.

\section{ADVANCES IN TISSUE BANKING (Vol. 7)}

Copyright $(2004$ by World Scientific Publishing Co. Pte. Ltd.

All rights reserved. This book, or parts thereof, may not be reproduced in any form or by any means, electronic or mechanical, including photocopying, recording or any information storage and retrieval system now known or to be invented, without written permission from the Publisher.

For photocopying of material in this volume, please pay a copying fee through the Copyright Clearance Center, Inc., 222 Rosewood Drive, Danvers, MA 01923, USA. In this case permission to photocopy is not required from the publisher.

ISBN $981-238-723-4$ 


\section{ADVANCES IN TISSUE BANKING}

\section{International Advisory Board}

H. Burchardt, USA

A. Gross, Canada

M. Itoman, Japan

J. Kearney, UK

J. Komender, Poland

B. Loty, France

P. Mericka, Czech Republic

D.A.F. Morgan, Australia

D. Pegg, UK

M. Salai, Israel

W.W. Tomford, USA

Y. Vajaradul, Thailand

H. Winkler, Austria

N. Yusof, Malaysia

N. Triantafyllou, Greece

R. Capanna, Italy

W.W. Boeckx, Belgium

C.J. Yim, Korea 


\section{LIST OF CONTRIBUTORS}

JORGE MORALES

IAEA Department of Technical Cooperation

Vienna, Austria

GLYN O. PHILLIPS

Phillips Hydrocolloids Research Ltd.

2 Plymouth Drive Radyr, Cardiff CF15 8BL, UK

TED EASTLUND

Division of Transfusion Medicine

Department of Laboratory Medicine and Pathology

University of Minnesota Medical School

Minneapolis, Minnesota 55455, USA

D. MICHAEL STRONG

Puget Sound Blood Center/Northwest Tissue Centre 921 Terry Ave, Seattle, Washington 98104, USA

JEROEN VAN BAARE, STEPHAN VEHMEIJER and ROLF BLOEM

Netherlands Bone bank Foundation,

Portgebouw Noord, Rijrisburgerweg 10

2333 AA Leiden, The Netherlands

OCTAVIO V. MARTINEZ

University of Miami Tissue Bank

Department of Orthopaedics (R-12)

University of Miami, PO Box 016960

Miami, Florida, US 33101 


\section{AXEL PRUSS}

Institute for Transfusion Medicine, Tissue Bank

University Hospital Charité

Schumannstr. 20/21, D-10117, Berlin

MOUJAHED KAO and GEORG PAULI

Robert Koch-Institut, Retrovirology

Norduter 20, D-13353, Berlin, Germany

MARTELL WINTERS

Bioburden Section Leader,

Nelson Laboratories, Inc.

6280 South Redwood Road

Salt Lake City, UT 82123

Y. YU, J.B. CHEN, J.-L. YANG and W.R. WALSH

Orthopaedic Research Laboratories

Prince of Wales Hospital

University of New South Wales

Sydney 2031 NSW, Australia

R. VERHEUL, N. JOHNSON and D.A.F. MORGAN

Queensland Bone Bank

Princess Alexandra Hospital Health Service District

Wooloongabba 4102 QLD, Australia

\section{LARS FROMMELT}

Institut für Infektiologie

klinische Mikrobiologie und Krankenhaushygiene

ENDO-KLINIK Holstenstr. 2, D-22607 Hamburg

LUTZ GÜRTLER

Friedrich Loeffler Institut für Medizinische Mikrobiologie Ernst Moritz Arndt Universität, Matin-Luther-Strasse

D-17487 Greifswald 
THOMAS VON GARREL

Klinik für Unfall-, Wiederherstellungs- und Handchirurgie Philipps Universität, Baldingerstrasse, D-35043 Marburg

\section{PAUL L. ROMAIN}

Department of Rheumatology

The Cambridge Hospital

1493 Cambridge Street, Cambridge, MA 02139

JEROEN VAN BAARE

Netherlands Bone bank Foundation

Portgebouw Noord, Rijnsburgerweg 10

2333 AA Leiden, The Netherlands

\section{GER KROPMAN}

Euro Skin bank, Beverwijk, The Netherlands

\section{MARCO ANTONIO GARCES MORALES} and CESER ALEJANDRO REYNAGA LUNA Plastic and Burns Department Hospital Nacional Arzobispo Loayza Av. Alfonso Ugarte s/n Lima, Peru

\section{HENRY J. MANKIN}

Orthopaedic Oncology Service Massachusetts General Hospital Harvard Medical School, Boston, MA 02114

WONG YONG SHON, CHANG YONG HUR and SOONG HYUN JUNG

Department of Orthopaedic Surgery

Guro Hospital, Korea University

\#80, Guro-Dong, Guro-Ku, Seoul, Korea 152-703 
PETR VISNA

Traumatological Hospital

Ponavka 6, 60200 Brno, Czech Republic

\section{JIRI ADLER}

Tissue Bank, University Hospital Brno

Czech Republic

L. PASA and R. HART

Traumatological Hospital Brno

Czech Republic

\section{J. FOLVARSKY}

University Hospital, Hradec Kralové

Czech Republic

V.I. SAVELIEV, I.A. KUZNETSOV, A.V. KALININ, A.A. BULATOV and I.A. SOLODOV

Russian Research Institute of Traumatology and Orthopaedics named after R.R. Vreden

Baikov Str. 8, 195427 St. Petersburg, Russia

\section{A.V. KALININ, V.I. SAVELIEV and A.A. BULATOV}

Russian Research Institute of Traumatology and Orthopaedics, named after R.R. Vreden

Baikov Str. 8, 195427 St. Petersburg, Russia

\section{LUCA DAINESE, GIANLUCA POLVANI,} ANNA GUARINO and PAOLO BIGLIOLI

Department of Cardiac Surgery

University of Milan-Italian Homograft Bank (BIO)

Centro Cardiologico Monzino, IRCCS

Via Parea 4, 20138 Milan, Italy 


\section{MARILENA FORMATO}

Department of Physiological, Biochemical and

Cellular Sciences, University of Sassari

Via Muroni 25, 07100 Sassari, Italy

HAN-KI PARK, YOUNG-HWAN PARK, SANG-HYUN LIM, JONG-HOON KIM, and BUM-KOO CHO

Yonsei Cardiovascular Research Institute

Cardiovascular Hospital

Yonsei University College of Medicine

134 Shincheondong, Seodaemunku, Seoul, Korea

\section{SANG-HO CHO}

Department of Pathology

Yonsei University, College of Medicine

134 Shincheondong, Seodaemunku, Seoul, Korea

JONG-CHUL PARK and DONG-WOOK HAN

Department of Medical Engineering

Yonsei University, College of Medicine

134 Shincheondong, Seodaemunku, Seoul, Korea

\section{CHEE-SOON YOON}

Department of Thoracic and Cardiovascular Surgery College of Medicine, Konyang University 685 Gasuwondong, Seogu, Daejun, Korea

\section{SHI-HO KIM}

Department of Thoracic and Cardiovascular Surgery College of Medicine, Donga University 3-1 Dongdaesindong, Seogu, Pusan, Korea

\section{SAM-YOON LEE}

Department of Thoracic and Cardiovascular Surgery College of Medicine, Wonkwang University 344-2 Shinyongdong, Iksanshi, Junrabukdo, Korea 
DORIS A. TAYLOR

Center for Cardiovascular Repair

University of Minnesota BSBE 7-105

312 Church Street $5 \mathrm{E}$

Minneapolis, MN 55455

\author{
SITARAM EMANI, MATTHEW ELLIS \\ and RICHARD B. THOMPSON \\ Departments of Medicine and Surgery \\ Duke University Medical Center \\ Box 3345, DUMC Durham, NC 27710 \\ DAGMAR HAVRANOVA, JIRI ADLER, \\ JANA KOMARKOVA, ANNA TEJKALOVA \\ and EVA HLAVACKOVA \\ Tissue Bank, University Hospital Brno \\ Jihlavská 20, 62500 Brno, Czech Republic
}

EVA VLKOVA, HANA HRUBA and MONIKA HORACKOVA Ophthalmology Department

University Hospital Brno

Jihlavská 20, 62500 Brno, Czech Republic

MAHMOOD FARAZDAGHI

Tissue Banks International, 815 Park Avenue, Baltimore, Maryland 21201, USA

SONJA GRUNEWALD, UWE PAASCH and HANS-JUERGEN GLANDER

Department of Dermatology/Division of Andrology University of Leipzig, Stephanstrasse 11

D-04103 Leipzig, Germany 
CORNELIA THIEME, UWE PAASCH and HANS-JUERGEN GLANDER

Department of Andrology, University of Leipzig

Stephanstrasse 11

04103 Leipzig, Germany

YOUNG-HWAN PARK, DONG-WOOK HAN and JONGCHUL PARK

Department of Thoracic and Cardiovascular Surgery

Yonsei Cardiovascular Research Institute

Cardiovascular Hospital

Yonsei University College of Medicine

134 Shincheondong, Seodaemunku, Seoul, Korea

SHI-HO KIM

Department of Thoracic and Cardiovascular Surgery, Donga University College of Medicine

3-1 Dongdaesindong, Seogu, Pusan, Korea

SCOTT A. BARBOUR and WARREN KING

Palo Alto Medical Foundation

Palo Alto, California 
This page is intentionally left blank 


\section{PREFACE}

With confidence I can say that this is the most comprehensive volume dealing with tissue banking presently available. There are 27 full chapter contributions from the most distinguished and experienced practitioners in the subject: surgeons, microbiologists, and tissue bankers. The volume deals with all the major facets of tissue banking and utilisation: procurement processing, and utilisation.

\section{Safety of Tissues (Section II)}

Safety of allografts is now a major concern due to microbial and viral contamination of tissues even in the most sophisticated centres. Thus publication here of the International Atomic Energy Agency's Code of Practice for the Radiation Sterilisation of Tissues is an important event, as is their guidance on Standards and Public Awareness of this often misunderstood technology.

There is now convincing evidence that safety has been compromised by certain regimes used to prepare human tissues for transplantation. Drs Eastland and Strong document fully the diseases which have been transmitted though tissues, in some instances, leading to fatalities. Thereafter, Section 2 continues to provide an in-depth investigation of this problem, particularly in bone and a consideration of safe and effective methods to use such tissues. The University of Miami Tissue Bank has been a leader in methods of microbiological screening of donors, and the final tissues. Dr Martinez (Chapter 5) delivers this experience concisely to us. The potential presence of viruses poses a formidable challenge to the tissue banker, and even when introducing an end-sterilisation radiation step, the outcome is 
not clear-cut. Dr Axel Pruss and colleagues (Chapter 6) have taken us forward in a giant step in their careful controlled study of this problem.

All roads seem now to lead to the desirability of adopting an end-sterilisation process if safe tissue are to be guaranteed (Chapter 7). When ionising radiation is used as part of a standardised working system of a tissue bank, then a degree of sterility assurance can be achieved. The IAEA programme has devoted considerable resources to define such procedures and the Code of Practice (Chapter 8) and Standards (Chapter 9) within which such a Code should be employed. There are limits to such use of radiation for bone, depending on the effects of radiation on mechanical strength and osteoinductivity (Chapter 10) of the final product. It is necessary to evaluate this aspect as $\mathrm{Dr} \mathrm{Yu}$ and colleagues have done.

The Marburg Bone Sterilisation Process for femoral heads may not have a universal application, but its effectiveness when properly used cannot be denied, as demonstrated by Dr von Garrel and his colleagues (Chapter 11).

\section{Ethical and Social Attitudes (Section III)}

The social and legal problems which arose in the UK, as a result of the unlawful procurement of tissues, have adversely affected public attitudes towards the procurement of tissues for cadaveric donors. Dr Paul L. Romain (Chapter 12) sets out in stark terms the ethical challenges which this field now poses. The justification for the practice remains the health benefits which such donation permits. In particular, the availability of such tissues in the wake of disasters such as has been experienced first in the Netherlands (Chapter 13) and then in Peru (Chapter 14) is evaluated. These contributions provide the perfect justification for having a ready supply of safe tissue grafts for immediate treatment of burns or traumatic damage. 


\section{Tissue Grafts in Orthopaedics (Section IV)}

The main customers of tissue banks continue to be orthopaedic surgeons. In this volume we are privileged to have an outstanding contribution from the doyen of this valuable technology - Dr Henry Mankin (Chapter 15). What a contribution he has made, and how glad we all are that he continues to be active and inspire further his one-time students, who are now distinguished exponents in their own right. This section demonstrates again the value of using both fresh and processed allografts in revision arthroplasty, and knee defects (Chapters 16 and 17). For the first time in this series we are able to learn of the long Russian experience in this field (Chapter 18 and 19).

\section{Other Areas Covered (Sections V-VIII)}

Cardiovascular grafts sperm banking and controlled process for the cryopreservation of tissues (Chapters 24-27) are other subjects covered in this volume. The motivation for such a comprehensive volume came in the Congress held in Boston which drew together all the international associations of tissue banking: American, Asia Pacific, Latin American and European. The whole world has been harnessed to construct this outstanding and historic volume.

Glyn O. Phillips Editor-in-Chief 
This page is intentionally left blank 


\section{CONTENTS}

List of Contributors vii

Preface $\quad$ xv

Section I: The Contribution of the International Atomic Energy Agency (IAEA) to Tissue Banking

Chapter 1 The International Atomic Energy Agency (IAEA) Programme in Radiation and

Tissue Banking: Past and Present

Chapter 2 IAEA Public Awareness Strategies for Tissue Banks

Section II: Safety of Tissue Allografts

Chapter 3 Infectious Disease Transmission through Tissue Transplantation

Chapter 4 Bacterial Contamination of Bone Allografts in The Netherlands

Chapter 5 Microbiological Screening of Cadaver Donors and Tissues for Transplantation

Chapter 6 Safety of Virus Inactivation Methods for Allogeneic Avital Bone Tissue Transplants

Chapter 7 Methods of Culturing, Problems Associated with Bacteriostasis, and Radiation Sterilisation Options 
Chapter 8 IAEA Code of Practice for the Radiation

Sterilisation of Tissue Allografts:

Requirements for Validation and

Routine Control

Chapter 9 IAEA International Standards for

Tissue Banks

Chapter 10 In Vivo Assessment of Gamma Irradiated Bone: Osteoconductivity and Osteoinductivity

Chapter 11 Disinfection of Femoral Heads for Bone Grafting Using the Marburg Bone Bank System (Lobator Sd 1) - A Retrospective Evaluation of Quality Control in the Endo-Klinik Bone Bank

Section III: Ethical and Social Aspects of Tissue Banking

Chapter 12 Tissue Banking and Transplantation: The Ethical Challenges

Chapter 13 The Volendam Burn Disaster and the Importance of International Collaboration in Tissue Banking

Chapter 14 The Need for a Tissue Bank in a Disaster: Experience in Arzobispo Loayza National Hospital after the Tragedy in "Mesa Redonda", Lima, Peru

Section IV: Tissue Grafts in Orthopaedics

Chapter 15 Major Limb Reconstruction Using Massive Cadaveric Allografts

Chapter 16 Revision Arthroplasty Using Fresh Frozen Allograft with Cemented Cup for Acetabular Bone Deficiency 
Chapter 17 Present Ways of Treating Chondral and Osteochondral Knee Defects

Chapter 18 Knee Joint Ligament Alloplasty with

Tendon Grafts Sterilised with Gaseous

Ethylene Oxide

Chapter 19 New Approaches to Comparative

Evaluation of Allogenic and

Autologous Bone Transplants

Procured in Various Ways

Section V: Cardiovascular Grafts

Chapter 20 Cryopreservation of Porcine Aortic Valve:

Open Status of the Aortic Leaflets Results in Increased Matrix Glycosaminoglycans Structural Maintenance

Chapter 21 Pathologic Changes of the Cryopreserved Carotid Artery and Jugular Vein Implanted at the Canine Carotid Artery

Chapter 22 Cellular Therapy for Heart Failure:

A Review of Skeletal Myoblast

Transplantation into Infarcted

Myocardium

Section VI: Cornea Grafts

Chapter 23 Cornea Transplantation Strategy -

Organ Culture versus Cold Storage

Section VII: Sperm Banking

Chapter 24 Characterisation and Depletion of Membrane Deteriorated Human Spermatozoa After Cryopreservation 
Chatper 25 A Repository System for Cryopreserved Semen Samples and Testicular Biopsies Embedded in a Workflow Management System

Section VIII: Cryopreservation

591

Chapter 26 Finding the Ideal Freezing Curve for Tissues through Indirect Themophysical Calculation 593

Chapter 27 The Safe and Effective Use of Allograft Tissue: An update 